\title{
Rancang Bangun Aplikasi Lokasi Bus Rapid Transit (BRT) Berbasis Global Positioning System (GPS) dan SMS Gateway
}

\author{
Reynold Tjandi ${ }^{1)}$, Gigih Forda Nama ${ }^{2)}$, Meizano Ardhi Muhammad ${ }^{3)}$ \\ ${ }^{1)} J u r u s a n$ Teknik Elektro, Fakultas Teknik, Universitas Lampung \\ Jl. Soemantri Brojonegoro No. 1 Bandarlampung 35145 Telp 0721-785508 Fax 0721-785508
}

\begin{abstract}
Saat ini, Bus Rapid Transit (BRT) Bandar Lampung tidak memiliki informasi mengenai lokasi BRT. Ketiadaan informasi mengenai lokasi BRT menyebabkan pengguna merasa kesulitan dan memilih angkutan umum lainnya. Dari hasil survey yang dilakukan, banyak pengguna membutuhkan informasi untuk mengetahui lokasi BRT dan estimasi waktu ke halte. Sehingga dibangun aplikasi lokasi BRT untuk menjawab kebutuhan pengguna. Penelitian ini dilakukan dengan menggunakan metode extreme programming yang terdiri dari planning aplikasi BRT, design berupa mockup aplikasi dan CRC card, coding yaitu pembuatan aplikasi BRT secara pair programming, testing dilakukan dengan acceptance testing, dan release berupa tampilan aplikasi webGIS BRT dan sistem SMS Gateway.

Hasil dari Penelitian ini berupa webGIS BRT yang memiliki informasi berupa lokasi bus, lokasi halte, rute yang digunakan, dan daftar halte berdasarkan rute. Selain itu dengan teknologi SMS Gateway, pengguna dapat melakukan SMS ke server untuk mengetahui estimasi waktu bus ke halte pengguna.

Kata kunci - BRT; Extreme Programming; WebGIS; SMS Gateway.
\end{abstract}

\section{I.PENDAHULUAN}

Transportasi di Indonesia khususnya di Bandar Lampung semakin berkembang, salah satunya adalah transportasi umum. Salah satu transportasi umum yang sering digunakan adalah Bus Rapid Transit (BRT). BRT di Bandar Lampung secara umum tidak jauh berbeda dengan BRT di kota-kota besar seperti Jakarta, Bandung, Surabaya, dan kota besar lainnya. Dengan biaya yang murah dan nyaman, maka transportasi menjadi sering digunakan oleh masyarakat.

Kekurangan dari BRT yaitu jadwal kedatangan bus yang tidak jelas. Masalah tersebut dapat diatasi dengan sistem pelacak posisi kendaraan menggunakan Global Possitioning System (GPS). Kemampuan yang dapat diberikan oleh GPS yaitu dapat memberikan informasi mengenai posisi, kecepatan, dan waktu secara cepat, akurat, dan dimana saja tanpa tergantung cuaca. Pemanfaatan sinyal GPS didukung dengan perangkat lainnya seperti antena GPS sebagai penangkap sinyal yang kemudian diproses oleh GPS receiver. Penambahan perangkat seperti GPS receiver, mikrokontroler, dan modem yang telah di integrasikan sedemikian rupa pada kendaraan dapat memungkinkan kendaraan bisa diketahui posisi kendaraan selama kendaraan tersebut masih dalam jangkauan provider GSM (Global System for Mobile Communication).

Lokasi pada BRT akan disimpan dalam sebuah database Geographic Information System (GIS). GIS merupakan sistem informasi khusus yang mengelola data yang memiliki informasi spasial (bereferensi keruangan) dan memiliki kemampuan untuk membangun, menyimpan, mengelola dan menampilkan informasi bereferensi geografis. GIS dalam sebuah server, lokasi seperti keberadaan halte, lokasi bus, dan perencanaan rute bus dapat disimpan dalam sebuah database.

Penyampaian lokasi bus ke pengguna jasa bus diperlukan suatu media pengirim informasi yang cepat dan tepat. Salah satu media pengirim informasi yang cepat dan tepat adalah melalui Short Message Service (SMS). Kemampuan dari SMS yaitu mengirimkan sebuah informasi berupa pesan teks yang akan langsung diterima melalui via handphone.

Salah satu pengembangan dari SMS yaitu SMS Gateway. SMS Gateway merupakan suatu platform yang menyediakan mekanisme untuk mengirim dan menerima SMS dari peralatan mobile (HP, PDA phone, dll) melalui SMS Gateway's shortcode (sebagai contoh 9221). Dengan SMS Gateway, sebuah aplikasi dapat mengirim sebuah informasi ke perangkat komunikasi lainnya dengan mengirimkan perintah Advanced Technology (AT) pada perangkat komunikasi tersebut, kemudian hasil operasinya dikirimkan kembali ke komputer.

Teknologi yang sudah ada hingga saat ini maka dapat diciptakan sebuah server lokasi real time BRT yang dapat mempermudah pengguna jasa BRT untuk mengetahui lokasi keberadaan bus dan waktu tempuh yang diperlukan dari dari halte sebelumnya ke halte berikutnya. Dengan kebutuhan pengguna akan layanan jasa BRT sehingga mengangkat judul "Rancang Bangun Aplikasi Lokasi Bus Rapid Transit Berbasis GPS dan SMS Gateway".

\section{TINJAUAN PUSTAKA}

Pada penelitian yang telah dilakukan oleh penulis [7], Peneliti membuat sebuah simulasi sistem informasi geografis pemantauan posisi kendaraan menggunaakan SMS gateway sebagai media pengiriman informasi dari mikrokontroler ke server.

Pada penelitian lain yang telah dilakukan penulis [9], Peneliti membuat web based GIS untuk layanan publik di Bandar Lampung. Peneliti menggunakan fitur google maps api untuk 
menampilkan peta dan menampilkan informasi layanan publik yang terdiri dari pasar tradisional, pabrik, kantor polisi, dan lain-lain.

Dengan teknologi yang sudah ada hingga saat ini maka penelitian skripsi ini akan membahas pembangunan aplikasi lokasi BRT.

Sistem aplikasi yang dibangun dengan menggunakan fitur google maps api untuk mengetahui lokasi BRT dan penggunaan SMS gateway sebagai penyampaian informasi dari BRT ke server dan server ke pengguna.

\section{Geographic Information System}

Geographic Information System (GIS) merupakan sistem informasi khusus yang mengelola data berupa data spasial (bereferensi keruangan) yang dirancang untuk bekerja dengan data yang berkoordinat geografi. Dengan kata lain, GIS merupakan sistem komputer yang memiliki kemampuan dalam membangun, menyimpan, mengelola dan menampilkan informasi bereferensi geografis. Dengan adanya GIS dapat menampilkan informasi yang telah diolah dan tersimpan sebagai atribut suatu lokasi. Komponen dalam pembuatan GIS terdiri dari hardware berupa spesifikasi server yang bertujuan untuk mengolah data GIS, software untuk mengolah data, menyimpan, editing, hingga layout dan analisis keruangan, sumber daya manusia yang mendesain dan memelihara sistem, data yang berupa data spasial dan data atribut [1] [2].

\section{A. Data Vektor}

Data vektor merupakan data yang mepresentasikan keadaan bentuk bumi dalam bentuk kumpulan line, polygon, dan node [3]. Data tersebut ditujukkan pada gambar 1 .

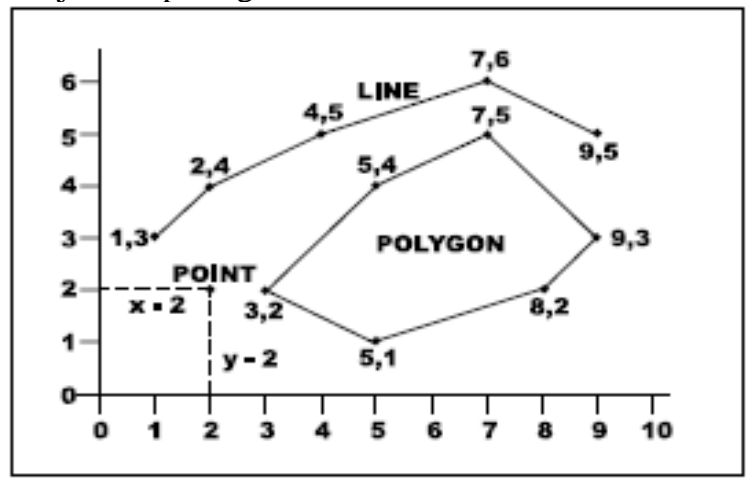

Gambar 1 .Data Vektor

\section{B. Data Raster}

Data raster merupakan data yang dihasilkan dari sistem penginderaan jauh seperti melalui satelit, foto, dan lain-lain dan direpresentasikan dalm bentuk sel grid yang disebut pixel [3]. Bentuk dari data raster ditujukkan pada gambar 2.

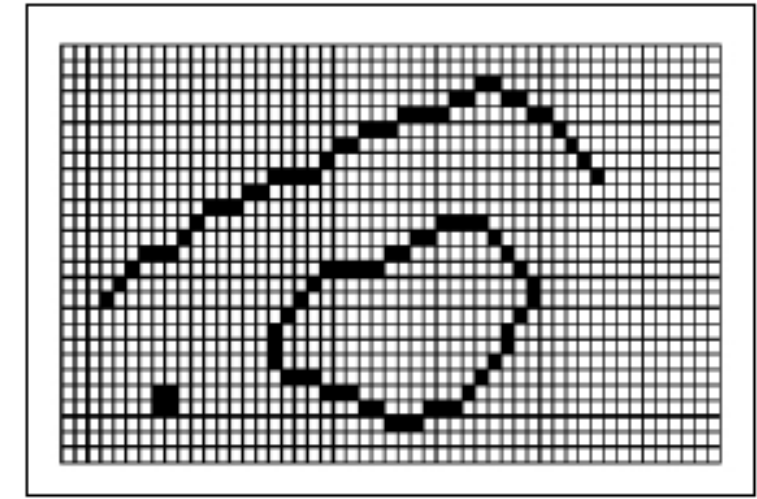

\section{Server WebGIS}

Gambar 2. Data Raster.

Server WebGIS digunakan untuk menunjukkan desain map pada sisi server dan menampilkannya dalam bentuk web application [4]. Bentuk arsitektur webGIS ditunjukkan pada gambar 4.

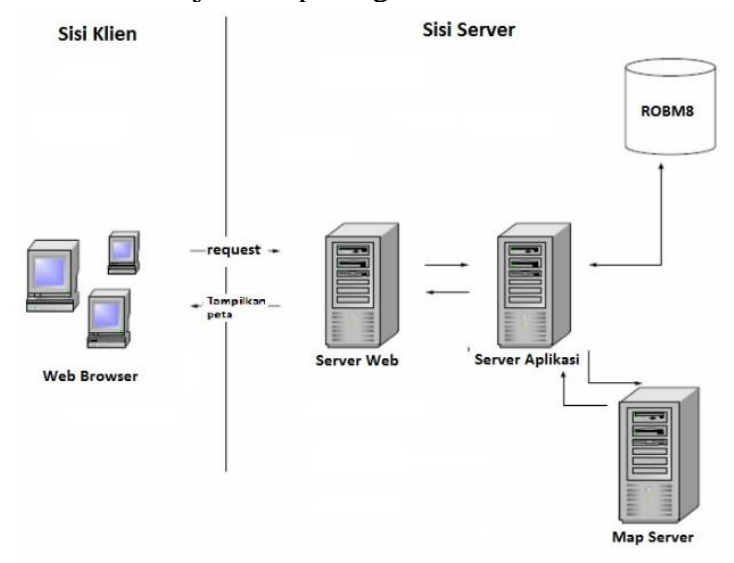

Gambar 4. Arsitektur GIS Berbasis Web

\section{Sistem Database}

SQL (Structured Query Language) adalah sebuah DBMS (Database Management System) yang digunakan untuk pengolahan dan penyimpanan data. SQL dibuat oleh perusahaan Microsoft. Salah satu software database yaitu MySQL. MySQL merupakan implementasi dari sistem RDBMS (Relational Database Management System) yang didistribusikan secara gratis dengan dibawah lisensi GPL (General Public License) [1] [5]. Bentuk perancangan database ditunjukkan pada gambar 5 .

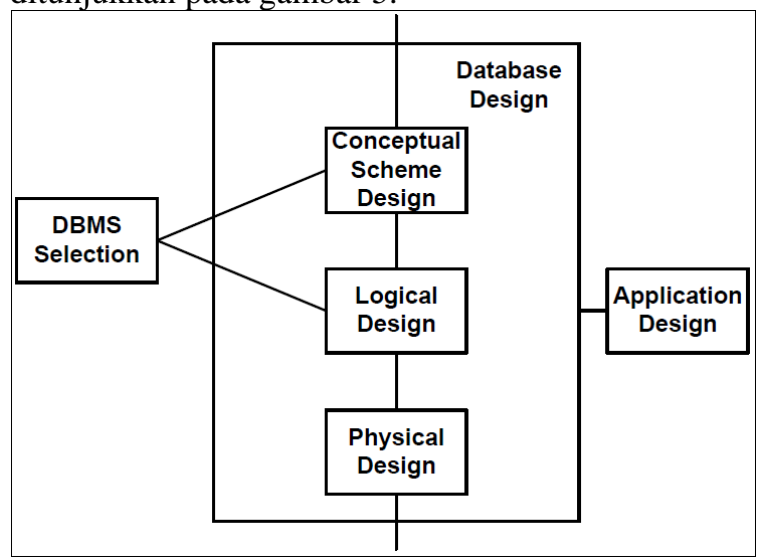


Gambar 5. Metode Perancangan Database

\section{SMS Gateway}

SMS Gateway merupakan sebuah media platform yang digunakan untuk mengirimkan informasi berupa teks dari perangkat satu ke perangkat lain. Salah satu software SMS gateway yaitu Gammu SMS gateway. Gammu SMS Gateway merupakan aplikasi cross-platform yang digunakan untuk mengomunikasikan antara database SMS Gateway dengan perangkat pengirim SMS [1] [6]. Cara kerja SMS gateway ditunjukkan pada gambar 6.

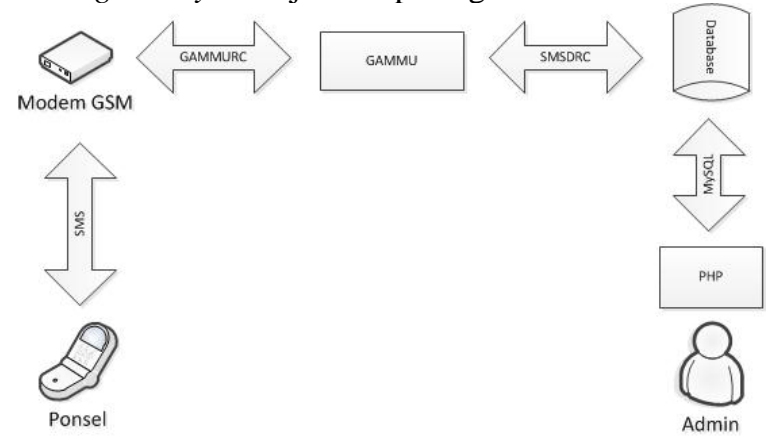

Gambar 6. Cara Kerja SMS Gateway

\section{METODE PENELITIAN}

\section{Extreme Programming}

Extreme Programming atau XP adalah suatu metode rekayasa perangkat lunak yang mengadopsi pendekatan agile yang berfungsi untuk membantu meningkatkan efisiensi dan fleksibilitas dari sebuah proyek perangkat lunak [8].

Bentuk kerangka XP ditunjukkan pada gambar 7.

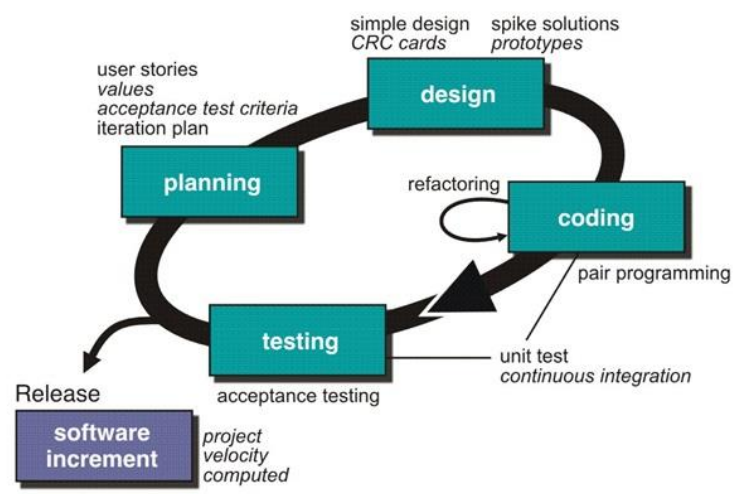

Gambar 7. Kerangka Kerja XP

\section{A. Planning}

Aktivitas planning dimulai dengan membuat gambaran tentang perangkat lunak yang dibuat dan menentukan estimasi waktu dan biaya yang akan dibutuhkan. Selama proses pengembangan perangkat lunak, programmer harus siap apabila terjadi perubahan rencana dari aplikasi yang dibuat [9].

Pada tahap planning terdiri dari user stories yaitu melakukan pertemuan langsung dengan customer dan menanyakan ke costumer tetang sistem yang akan dibuat; acceptance testing criteria yaitu menentukan kriteria acceptance testing dengan mencakup poin-poin seperti functional correctness and completeness, data integrity, data cobversion, usability, performance, timeliness, dan confidentiality and availability; dan iteration plan yaitu rencana yang akan dilakukan dalam pengerjaan suatu sistem [11].

\section{B. Design}

Aktivitas design bertujuan untuk mengatur pola logika dalam sistem supaya mengurangi ketergantungan antar setiap proses pada sebuah sistem [8]. Tahap design terdiri dari simple design yang dibuat dalam bentuk mockup aplikasi. Tahap selanjutnya yaitu pembuatan CRC card yang berfungsi sebagai sebuah index card yang mempunyai tiga bagian, yaitu class yang menjelaskan berbagai objek, responsibility adalah sesuatu yang class dapat lakukan atau tidak, dan collaborator adalah kolaborasi antar class yang saling berinteraksi [10].

\section{Coding}

XP menerapkan konsep Pair Programming yang berarti setiap tugas sebuah modul dikembangkan oleh dua orang programmer. Pair Programming pada XP bertujuan untuk mempercepat proses pengerjaan perangkat lunak. Selanjutnya, modul aplikasi yang sudah selesai dibangun akan digabungkan dengan aplikasi utama [8]. Dalam tahap coding terdapat unit testing yang berfungsi untuk membantu pengembang untuk memeriksa apa saja yang harus diselesaikan. Sistem akan selesai jika semua unit testing berjalan dengan baik [11].

\section{Testing}

Pada tahap testing dilakukan acceptance testing yang dibuat dari user stories dan untuk menguji sistem berfungsi dengan baik. Pengguna bertanggung jawab untuk memverifikasi kebenaran dari acceptance testing dan meninjau hasil test untuk memutuskan mana yang gagal dan menentukan tes prioritas tertinggi [11].

\section{Planning}

A. User Stories

Untuk mengetahui minat pengguna dalam menggunakan jasa BRT sebagai layanan transportasi, maka dilakukan survei yang berisi tentang kepuasan layanan BRT terutama dalam managemen waktu. Survei dilakukan dengan cara penyebaran kuisioner dengan sampel sebanyak 20 buah kepada pengguna BRT. Dari survei yang dilakukan, maka pertanyaan 
yang muncul dari pengguna mengenai layanan BRT adalah:

- Apa yang diperlukan untuk meningkatkan layanan BRT?

- Sebagai pengguna, bagaimana cara pengguna mengetahui lokasi BRT dan waktu yang diperlukan untuk sampai ke pengguna?

Dari pertanyaan-pertanyaan tersebut, maka perancangan pembuatan aplikasi BRT dibuat dalam bentuk my canvas product. Dalam pembuatan my canvas product diambil 3 sampel pengguna untuk mengetahui keinginan pengguna. Bentuk my canvas product ditunjukkan pada tabel 1 .

Tabel 1. My canvas product

\begin{tabular}{|c|c|c|c|c|}
\hline \multicolumn{3}{|l|}{ User } & \multirow[t]{2}{*}{ Detail } & \multirow[t]{2}{*}{ Iteration Goal } \\
\hline Nama & Pekerjaan & Cerita & & \\
\hline Ernest & Pelajar & $\begin{array}{l}\text { Ingin } \\
\text { mengetahui } \\
\text { berapa lama } \\
\text { lagi bus } \\
\text { akan } \\
\text { sampai. }\end{array}$ & \multirow{3}{*}{ 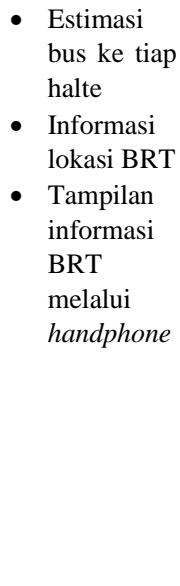 } & \multirow{3}{*}{ 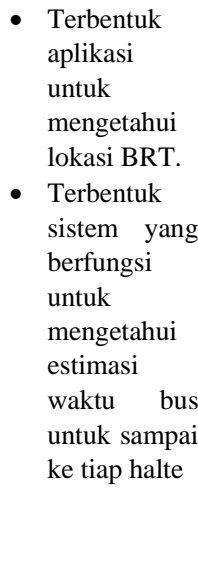 } \\
\hline Andi & Mahasiswa & $\begin{array}{l}\text { Membutuh } \\
\text { kan } \\
\text { informasi } \\
\text { lokasi BRT. }\end{array}$ & & \\
\hline Dimas & $\begin{array}{l}\text { Pegawai } \\
\text { Swasta }\end{array}$ & $\begin{array}{l}\text { Ingin } \\
\text { jadwal } \\
\text { kedatangan } \\
\text { BRT dapat } \\
\text { diakses } \\
\text { melalui } \\
\text { handphone. }\end{array}$ & & \\
\hline
\end{tabular}

\section{B. Acceptance Test Criteria}

Acceptance testing criteria mencakup user stories yang diberikan oleh pengguna BRT seperti managemen waktu BRT untuk sampai ke tiap halte dan layanan BRT yang diberikan. Kriteria yang digunakan dalam acceptance test ditunjukkan pada tabel 2.

Tabel 2. Acceptance test criteria

\begin{tabular}{|l|l|}
\hline Kriteria & Keterangan \\
Completeness & $\begin{array}{l}\text { Mengecek kebenaran dan } \\
\text { kelengkapan fungsi yang } \\
\text { diperlukan dalam aplikasi } \\
\text { BRT }\end{array}$ \\
\hline Data Integrity & $\begin{array}{l}\text { Mengecek sumber data yang } \\
\text { didapatkan }\end{array}$ \\
\hline Data Conversion & $\begin{array}{l}\text { Mengecek pengubahan data } \\
\text { SMS baik dari bus atau dari } \\
\text { pengguna }\end{array}$ \\
\hline Usability & $\begin{array}{l}\text { Mengecek kegunaan dari } \\
\text { aplikasi BRT }\end{array}$ \\
\hline Performance & $\begin{array}{l}\text { Mengecek performa dari } \\
\text { aplikasi BRT }\end{array}$ \\
\hline Timeliness & $\begin{array}{l}\text { Mengecek data lokasi bus } \\
\text { yang dikirimkan sesuai } \\
\text { dengan sebenarnya. }\end{array}$ \\
\hline
\end{tabular}

\begin{tabular}{|l|l|}
\hline $\begin{array}{l}\text { Confidentiality and } \\
\text { Availability }\end{array}$ & $\begin{array}{l}\text { Mengecek kerahasiaan dan } \\
\text { ketersediaan data baik dari } \\
\text { bus atau dari pengguna }\end{array}$ \\
\hline
\end{tabular}

\section{Iteration Plan}

Dalam pengerjaan server BRT berbasis GPS dan SMS Gateway terdapat estimasi waktu yang dibutuhkan dalam pengerjaan tiap modul. Tiap modul mencakup accpetance test criteria. Berikut adalah tabel tiap modul berdasarkan acceptance testing criteria yang ditunjukkan pada tabel 3.

Tabel 3. Iteration plan tiap modul berdasarkan acceptance testing criteria.

\begin{tabular}{|c|c|c|c|}
\hline & $\begin{array}{l}\text { WebGIS untuk } \\
\text { Administrator }\end{array}$ & $\begin{array}{l}\text { WebGIS untuk } \\
\text { Pengguna }\end{array}$ & SMS Gateway \\
\hline $\begin{array}{l}\text { Functional } \\
\text { Correctness and } \\
\text { Completeness }\end{array}$ & $\begin{array}{l}\text { Data yang } \\
\text { ditampilkan } \\
\text { baik dalam tabel } \\
\text { atau webGIS } \\
\text { sesuai dengan } \\
\text { data real }\end{array}$ & $\begin{array}{l}\text { Data yang } \\
\text { ditampilkan } \\
\text { pada webGIS } \\
\text { sesuai dengan } \\
\text { data real }\end{array}$ & \begin{tabular}{l} 
Data yang \\
dikirimkan \\
sesuai dengan \\
waktu terkecil \\
sesuai dengan \\
\multicolumn{2}{l}{ lokasi pengguna }
\end{tabular} \\
\hline Data Integrity & $\begin{array}{l}\text { Data lokasi bus } \\
\text { yang didapat } \\
\text { berasal dari } \\
\text { modul GPS } \\
\text { yang dikirimkan } \\
\text { melalui SMS }\end{array}$ & & $\begin{array}{lr}\text { Data waktu } \\
\text { yang didapat } \\
\text { pengguna } \\
\text { berasal dari } \\
\text { server. }\end{array}$ \\
\hline $\begin{array}{l}\text { Data } \\
\text { Conversion }\end{array}$ & $\begin{array}{l}\text { Parsing data } \\
\text { diperlukan } \\
\text { untuk } \\
\text { mengubah data } \\
\text { SMS bus dalam } \\
\text { data string } \\
\text { sesuai dengan } \\
\text { format yang } \\
\text { ditentukan } \\
\end{array}$ & & $\begin{array}{lr}\text { Parsing data } \\
\text { diperlukan } \\
\text { untuk } \\
\text { mengubah data } \\
\text { SMS pengguna } \\
\text { dalam data } \\
\text { string sesuai } \\
\text { dengan format } \\
\text { yang ditentukan }\end{array}$ \\
\hline Usability & $\begin{array}{l}\text { Berguna untuk } \\
\text { menampilkan } \\
\text { webGIS BRT } \\
\text { dan data bus. }\end{array}$ & $\begin{array}{l}\text { Berguna untuk } \\
\text { menampilkan } \\
\text { webGIS BRT }\end{array}$ & $\begin{array}{l}\text { Berguna untuk } \\
\text { mendapatkan } \\
\text { informasi bus } \\
\text { dengan } \\
\text { mengirimkan } \\
\text { SMS ke server. }\end{array}$ \\
\hline Performance & $\begin{array}{l}\text { Pengecekan } \\
\text { performa } \\
\text { meliputi } \\
\text { kesesuaian data } \\
\text { dan tampilan } \\
\text { webGIS melalui } \\
\text { browser }\end{array}$ & $\begin{array}{l}\text { Pengecekan } \\
\text { performa } \\
\text { meliputi } \\
\text { tampilan } \\
\text { webGIS melalui } \\
\text { browser }\end{array}$ & $\begin{array}{l}\text { Pengecekan } \\
\text { performa } \\
\text { meliputi lama } \\
\text { respon SMS } \\
\text { dari server ke } \\
\text { pengguna. }\end{array}$ \\
\hline Timeliness & $\begin{array}{l}\text { Data bus yang } \\
\text { ditampilkan } \\
\text { sesuai dengan } \\
\text { data sebenarnya. }\end{array}$ & $\begin{array}{l}\text { Data bus yang } \\
\text { ditampilkan } \\
\text { sesuai dengan } \\
\text { data } \\
\text { sebenarnya. }\end{array}$ & $\begin{array}{l}\text { Data estimasi } \\
\text { waktu yang } \\
\text { ditampilkan } \\
\text { sesuai dengan } \\
\text { data } \\
\text { sebenarnya. }\end{array}$ \\
\hline $\begin{array}{l}\text { Confidentiality } \\
\text { and Availability }\end{array}$ & $\begin{array}{l}\text { Meningkatkan } \\
\text { tingkat } \\
\text { keamanan } \\
\text { dengan cara } \\
\text { menggunakan } \\
\text { login untuk } \\
\text { mengakses } \\
\text { webGIS } \\
\text { administrator }\end{array}$ & & $\begin{array}{l}\text { SMS pengguna } \\
\text { diharuskan } \\
\text { sampai ke } \\
\text { pengguna sesuai } \\
\text { dengan nomor } \\
\text { yang digunakan } \\
\text { pengguna untuk } \\
\text { mengirim SMS } \\
\text { ke server }\end{array}$ \\
\hline
\end{tabular}




\section{Design}

Salah satu tahap design yaitu simple design yang bertujuan sebagai rancangan awal sebuah sistem dan fitur yang akan dibuat sesuai dengan tahap planning. Bentuk dari simple design ditunjukkan pada gambar 8 .

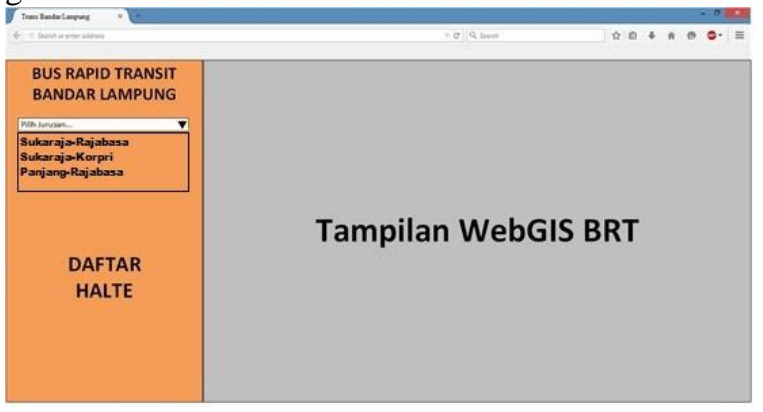

(a)

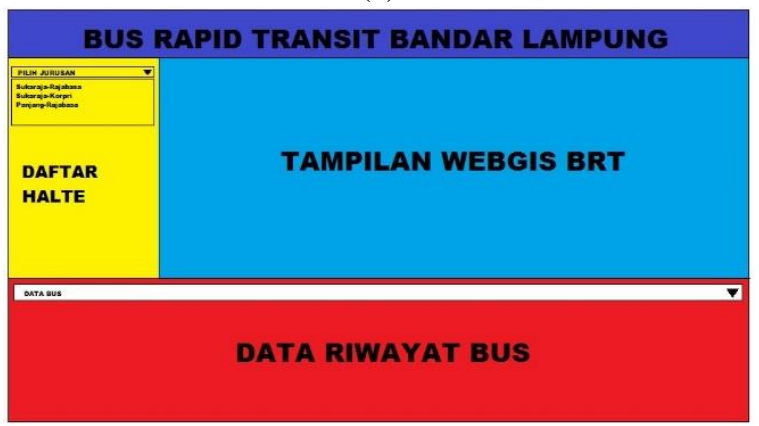

(b)

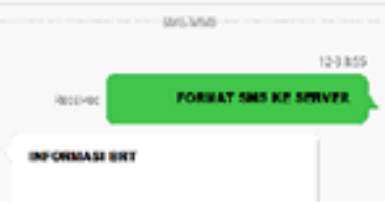

(c)

Gambar 8. (a) Simple Design WebGIS untuk Pengguna, (b) Simple Design WebGIS untuk Administrator, (c) Simple Design SMS Gateway

Bentuk arsitektur design aplikasi webGIS ditunjukkan pada gambar 9.

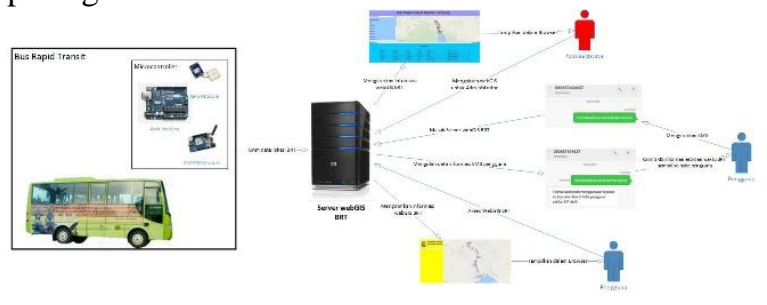

Gambar 9. Arsitektur Design

\section{Coding}

Salah satu yang menjadikan extreme programming sebagai metode yang paling efektif yaitu pair programming. Pair programming merupakan bentuk kerjasama dalam pembuatan aplikasi BRT. Dalam pembuatan aplikasi BRT terdiri dari satu tim yang beranggotakan dua orang programmer. Pembangunan aplikasi BRT terdiri dari empat modul yaitu modul microcontroller, modul webGIS untuk pengguna, modul webGIS untuk administrator, dan modul SMS gateway.

Modul microcontroller adalah modul yang berada pada BRT dimana modul tersebut akan mengirimkan lokasi bus ke server. Modul microcontroller terdiri dari GPS yang berfungsi untuk mengetahui posisi kendaraan dan modul SIM 900 yang berfungsi untuk mengirimkan informasi lokasi BRT dari microcontroller ke server.

Modul webGIS untuk pengguna berfungsi untuk menampilkan lokasi kendaraan dalam bentuk digitalisasi peta dan dapat diakses melalui web. Dalam pembuatan modul webGIS terdiri dari 2 bagian yaitu data raster yaitu peta google maps dan data vektor yaitu point bus, point halte, dan polyline rute. Bentuk dari data raster dan data vektor ditunjukkan pada gambar 9 .

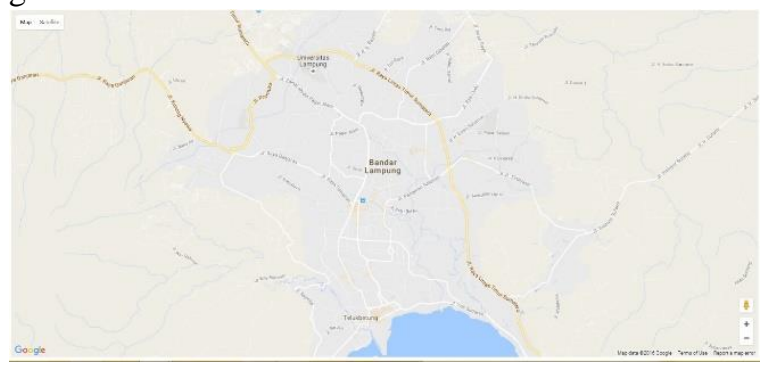

(a)

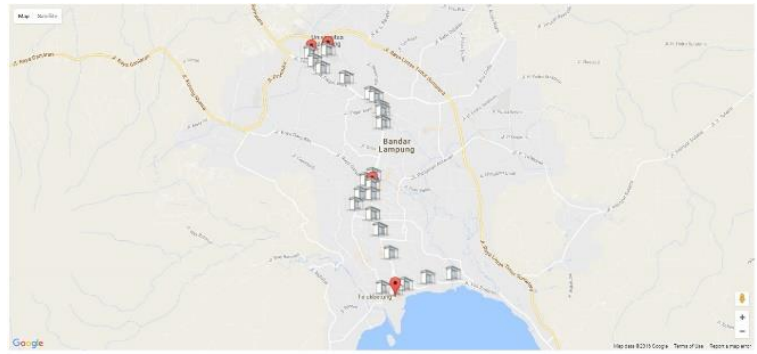

(b)

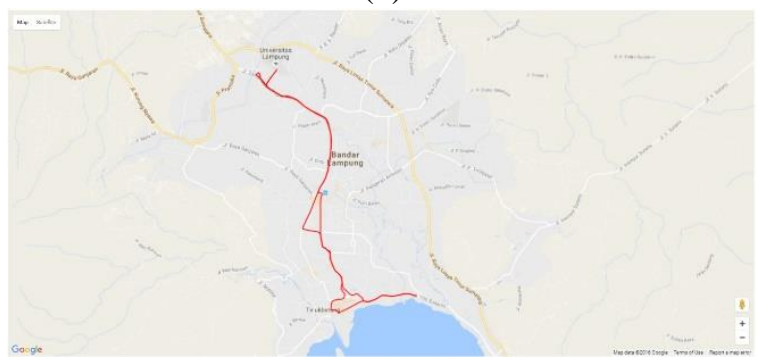

(c)

Gambar 9. (a) Data Raster, (b) Data Vektor Point, (c) Data Vektor Polyline

Pada modul webGIS untuk administrator memiliki fitur yang sama dengan webGIS untuk pengguna. Perbedaannya untuk webGIS ini memiliki tambahan fitur yaitu data bus berfungsi untuk mengetahui posisi terakhir BRT; data halte berfungsi untuk mengetahui BRT berada di halte mana 
berdasarkan radius dimana dalam menentukan radius menggunakan source code:

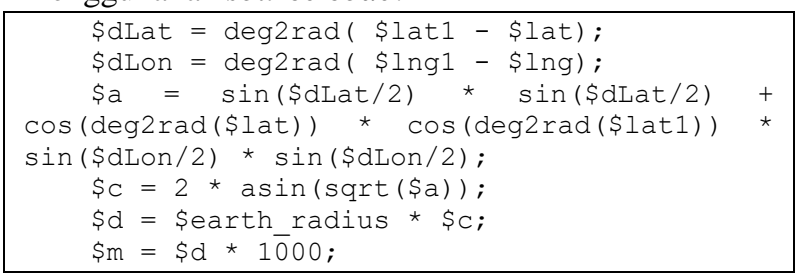

Data jarak berfungsi untuk mengetahui jarak antara bus dengan tiap halte dengan fitur google maps API distance matrix. Cara menggunakan fitur dari google maps API dengan menggunakan link berikut:

https://maps.googleAPIs.com/maps/api/distance matrix/json?origins=\$lat, $\mathbf{\$} \mathbf{l n g} \&$ destinations=\$1 at1,$\$$ lng1 \&mode=driving \& language=fr-

FR\&key=AI zaSyDNKgQXGaqpImRAOLtrlDNCpCmWts 639S $E^{\prime \prime}$

Pengujian performa perhitungan jarak dengan menggunakan google maps API ditunjukkan pada tabel 4.

Tabel 4. request dengan fitur google maps API.

\begin{tabular}{|l|l|l|}
\hline No & Jumlah request & Waktu respon (detik) \\
\hline 1 & 1 & 2 \\
\hline 2 & 5 & 4 \\
\hline 3 & 27 & 16 \\
\hline
\end{tabular}

Pada tabel 4 menunjukkan bahwa semakin banyak request menggunakan fitur google maps API, maka respon distance yang dihasilkan semakin lama.

Data waktu berfungsi untuk mengetahui estimasi waktu BRT ke tiap halte; dan History bus digunakan untuk mengetahui riwayat perjalanan bus.

Modul SMS gateway berfungsi untuk mengirimkan informasi dari pengguna ke administrator dan sebaliknya. Cara mengukur seberapa cepat respon yang diberikan, maka dilakukan pengukuran delay SMS. Data delay yang didapatkan ditunjukkan pada tabel 5 dan tabel 6 .

Tabel 5. Perhitungan delay dengan beda provider.

\begin{tabular}{|l|l|l|}
\hline $\begin{array}{l}\text { Waktu Pengiriman } \\
\text { SMS }\end{array}$ & $\begin{array}{l}\text { Waktu Penerimaan } \\
\text { SMS }\end{array}$ & Delay (detik) \\
\hline $2017-02-28$ & $2017-02-28$ & 138 \\
$13: 12: 15$ & $13: 14: 28$ & \\
\hline $2017-02-28$ & $2017-02-28$ & 87 \\
$13: 15: 23$ & $13: 16: 50$ & \\
\hline $2017-02-28$ & $2017-02-28$ & 148 \\
$13: 17: 33$ & $13: 20: 01$ & \\
\hline $2017-02-28$ & $2017-02-28$ & 64 \\
$13: 20: 38$ & $13: 21: 42$ & \\
\hline $2017-02-28$ & $2017-02-28$ & 115 \\
$13: 22: 12$ & $13: 24: 07$ & \\
\hline
\end{tabular}

Tabel 6. Perhitungan delay dengan provider yang sama.

\begin{tabular}{|l|l|l|}
\hline $\begin{array}{l}\text { Waktu Pengiriman } \\
\text { SMS }\end{array}$ & $\begin{array}{l}\text { Waktu Penerimaan } \\
\text { SMS }\end{array}$ & Delay (detik) \\
\hline 2017-03-05 & $\begin{array}{l}2017-03-05 \\
15: 53: 58\end{array}$ & 10 \\
\hline $2017-03-05$ & $2017-03-05$ & \\
$15: 55: 21$ & $15: 55: 34$ & 13 \\
\hline $2017-03-05$ & $2017-03-05$ & \\
$15: 57: 33$ & $15: 57: 46$ & 13 \\
\hline
\end{tabular}

\begin{tabular}{|l|l|l|}
\hline $2017-03-05$ & $2017-03-05$ & 15 \\
$16: 03: 17$ & $16: 03: 22$ & \\
\hline $2017-03-05$ & $2017-03-05$ & 12 \\
$16: 04: 42$ & $16: 04: 54$ & \\
\hline
\end{tabular}

Pada tabel 5 pengujian dilakukan dengan provider Telkomsel sebagai sim card yang digunakan pada server dan provider Three sebagai sim card yang digunakan oleh pengguna. Pengujian dilakukan dengan cara mengirimkan SMS dari pengguna ke server dan penghitungan dilakukan dengan cara menghitung selisih waktu antara waktu pengiriman SMS dari pengguna dan waktu penerimaan SMS dari server. Dari data yang didapatkan, delay rata-rata yang didapat pada lima percobaan yaitu 110,4 detik atau sekitar 1 menit 50,4 detik.

Pengujian pada tabel 6 yaitu menghitung delay dengan provider yang sama, yaitu dengan provider Telkomsel pada server dan pengguna. Dari hasil pengujian tersebut dilakukan dengan cara mengirim sms dari pengguna ke server sebanyak 5 kali dan hasil yang didapat pada percobaan yaitu didapatkan ratarata delay sebesar 12,6 detik.

Dari dua pengujian delay tersebut, penyebab delay yang begitu besar yaitu jaringan provider yang mengalami gangguan. Selain itu, performa server dalam mengolah sms dari pengguna menjadi penyebab sms yang lama dikirim, sehingga menimbulkan delay yang cukup besar.

\section{Testing}

Pada tahap testing, dilakukan acceptance testing untuk mengetahui apakah sistem sudah bekerja dengan baik atau tidak. Acceptance testing dilakukan dengan cara survei ke pengguna mengenai aplikasi BRT.

Tabel 7. Acceptance testing

\begin{tabular}{|l|l|l|}
\hline No & Acceptance Requirement & $\begin{array}{l}\text { Test } \\
\text { Result }\end{array}$ \\
\hline 1 & $\begin{array}{l}\text { Sistem bekerja sesuai dengan } \\
\text { kebenaran dan kelengkapan data. }\end{array}$ & $100 \%$ \\
\hline 2 & $\begin{array}{l}\text { Data yang didapatkan sesuai dengan } \\
\text { data yang sebenarnya }\end{array}$ & $100 \%$ \\
\hline 3 & $\begin{array}{l}\text { Pemecahan data string dari SMS } \\
\text { dan nilai yang didapatkan } \\
\text { dimasukkan ke dalam database }\end{array}$ & $\begin{array}{l}\text { Aplikasi BRT dapat berguna untuk } \\
\text { mengetahui lokasi bus dan estimasi } \\
\text { waktu bus ke tiap halte }\end{array}$ \\
\hline 5 & $\begin{array}{l}\text { Aplikasi BRT dapat bekerja dengan } \\
\text { baik tanpa gangguan }\end{array}$ & $72,72 \%$ \\
\hline 6 & $\begin{array}{l}\text { Lokasi bus dikirimkan sesuai } \\
\text { dengan data sebenarnya. }\end{array}$ & $100 \%$ \\
\hline 7 & Data bus terjami kerahasiaannya. & $100 \%$ \\
\hline
\end{tabular}




\section{Release}

Release dilakukan dengan tujuan untuk mengetahui fungsi pada aplikasi BRT bekerja dengan baik. Bentuk tampilan yang dihasilkan ditunjukkan pada gambar 10 .

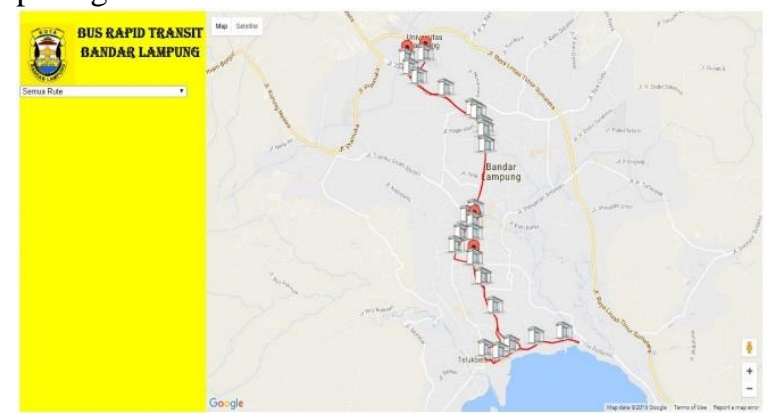

(a)

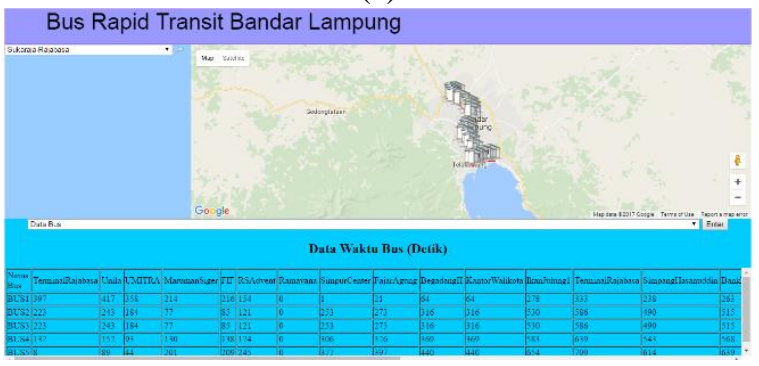

(b)

089657404637

Indonesia

SMS/MMS

Received

trans\#仿abasa-sukaraja\#tramayana

Terima kasih telah menggunakan layanan ini, bus akan tiba di halte pengguna sekitar 241 detik

(c)

Gambar 10. (a) WebGIS pengguna, (b) WebGIS administrator, (c) SMS gateway

Fitur yang ada pada webGIS pengguna seperti pada gambar 10 (a) yaitu terdapat peta google maps sebagai data raster, lokasi BRT terkini, rute yang dilewati BRT, dan lokasi halte berdasarkan rute. Selain itu, fitur yang ada pada administrator seperti pada gambar 10 (b) seperti dengan webGIS pengguna dengan tambahan informasi seperti data bus, data halte, data jarak, data waktu, dan history bus. SMS pengguna pada gambar 10 (c) menunjukkan estimasi waktu yang dibutuhkan BRT untuk sampai ke halte pengguna berdasarkan request pengguna.

\section{KESIMPULAN}

Terbangunnya aplikasi lokasi BRT memungkinkan pengguna untuk mengetahui lokasi bus sesuai kebutuhan dan dapat diakses melalui browser atau SMS.

Penelitian menggunakan metode extreme programming mengalami penyesuaian waktu karena diperlukan pembelajaran sebelum waktu iterasi pengembangan extreme programming.

Pengujian BRT berhasil sehingga pengguna dapat mengakses webGIS melalui browser untuk mengetahui lokasi bus, dan pengguna dapat mengirimkan SMS ke server dan mendapatkan balasan berupa estimasi waktu bus untuk sampai ke halte pengguna.

Pada tahap testing, rata-rata test result yang didapat sebesar 93,50\%. Hal ini menunjukkan bahwa aplikasi BRT dapat diterima oleh pengguna.

\section{DAFTAR PUSTAKA}

[1] A. R. Baskara, U. L. Yuhana, "Rancang Bangun Aplikasi SIG sebagai Sistem Peringatan Dini untuk Mitigasi Risiko Bencana Banjir dengan Pengingat Berupa SMS', Jurnal Teknik POM ITS, Volume 2, Issue 1, 2014.

[2] R. Astini, P. Oswald, "Modul Pelatihan Quantum GIS Tingkat Dasar", Mataram:GIZDecentralization as Contribution to Good Governance, 2012.

[3] GIS Konsorsium Aceh Nias, "Modul Pelatihan ArcGIS Tingkat Dasar", Aceh:Staf Pemerintahan Kota Banda Aceh, 2007.

[4] A. R. Tanaamah, R. Wardoyo, "Perancangan dan Implementasi WebGIS Pariwisata Kabupaten Sumba Timur", Jurnal Informatika, Volume 9, Issue 2, pp. 150-158, 2008.

[5] L. A. Abdillah, "Perancangan Basisdata Sistem Informasi Penggajian”, Jurnal Ilmiah MATRIKS, Volume 8, Issue 2, pp. 135-152, 2006.

[6] M. T. Muslih, B. E. Purnama, "Pengembangan Aplikasi SMS Gateway untuk Informasi Pendaftaran Peserta Didik Baru di SMAN 1 Jepara", Indonesian Jurnal on Networking and Security(IJNS), Volume 2, Issue 1, pp. 50-55, 2013.

[7] R. Hanifah, R. R. Isnanto, Y. Christyono, "Simulasi Sistem Informasi Geografis (SIG) Pemantau Posisi Kendaraan Via SMS Gateway", TRANSMISI, Volume 12, Issue 2, pp. 45-49, 2010.

[8] I. Sommervile, "Software Engineering", 9 ${ }^{\text {th }}$ ed, United State of America: Pearson Education Inc., 2011.

[9] G. F. Nama, M. Ulvan, A. Ulvan, A M Hanafi, "Design and Implementation of Web-Based 
Geographic Information System for Public Services in Bandar Lampung City - Indonesia", 2015 International Conference on Science in Information Technology (ICSITech 2015), ISBN: 978-1-4799-8384-1, pp. 270-275, 27-28 Oktober 2015 Yogyakarta, Indonesia.

[10] S. W. Amber, "Class Responsibility Collaborator (CRC) Models: An Agile”, diakses pada tanggal 10-01-2017, http://agilemodeling.com/artifacts/crcModel.ht

$\mathrm{m}$.

[11] D. Wells, "Extreme Programming", diakses pada tanggal 10-01-2017, http://www.extremeprogramming.org/ 